\title{
Correction to: Circular RNA circFGFR1 promotes progression and anti-PD-1 resistance by sponging miR-381-3p in non-small cell lung cancer cells
}

Peng-Fei Zhang ${ }^{1+}, \mathrm{Xu} \mathrm{Pei}^{2+}$, Ke-Sang $\mathrm{Li}^{3+}, \mathrm{Li}^{\mathrm{H}} \mathrm{Na} \mathrm{Jin}^{4 \dagger}$, Fei Wang ${ }^{1 *}$, Jing $\mathrm{Wu}^{1 *}$ and Xue-Mei Zhang ${ }^{1 *}$

\author{
Correction to: Mol Cancer \\ https://doi.org/10.1186/s12943-019-1111-2
}

After the publication of this work [1], an error was found in Fig. 1b. As described in the Results section that circ0084003 has 13 exons, it should be formed by $5-17$ (13exons) exons, authors have described "formed by 5-19 exons". The authors extend their apology for the mistake caused by their action. With that mistake, the correct version of Fig. $1 \mathrm{~b}$ is provided below.

B

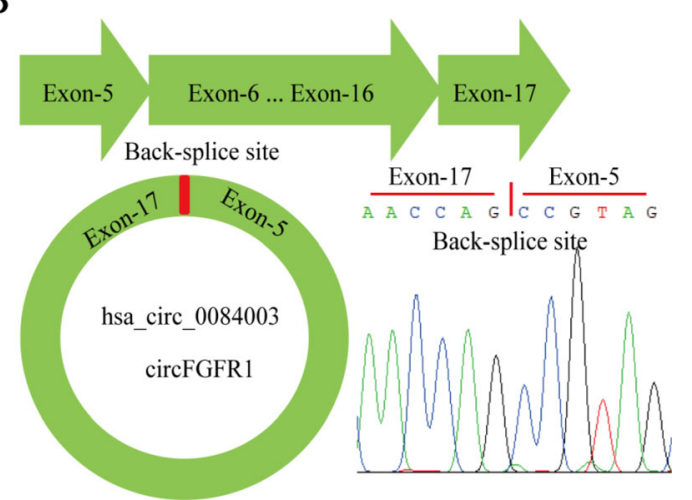

\section{Author details}

${ }^{1}$ Department of Oncology, Shanghai East Hospital, Tongji University School of Medicine, Shanghai, China. ${ }^{2}$ Department of Cardiothoracic Surgery, the Second Affiliated Hospital of Nanchang University, Nanchang, Jiangxi, China. ${ }^{3}$ Department of Hematology and Oncology, Hwa Mei Hospital, University of Chinese Academy of Sciences, Zrhejiang, Ningbo, China. ${ }^{4}$ Department of Hematology, Shanghai East Hospital, Tongji University School of Medicine, Shanghai, China.

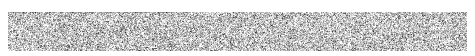

\section{Reference}

1. Zhang P-F, Xu P, Li K-S, Jin L-N, Wang F, Wu J, Zhang X-M. Circular RNA circFGFR1 promotes progression and anti-PD-1 resistance by sponging miR381-3p in non-small cell lung cancer cells. Mol Cancer. 2019;18:179 https:// doi.org/10.1186/s12943-019-1111-2.

The original article can be found online at https://doi.org/10.1186/s12943019-1111-2

*Correspondence: wf83515747@163.com; bunny23@126.com;

tju_zxm@163.com

${ }^{\dagger}$ Peng-Fei Zhang, Xu Pei, Ke-Sang Li and Li-Na Jin contributed equally to this work.

${ }^{1}$ Department of Oncology, Shanghai East Hospital, Tongji University School of Medicine, Shanghai, China

Full list of author information is available at the end of the article

(c) The Author(s). 2020 Open Access This article is distributed under the terms of the Creative Commons Attribution 4.0 International License (http://creativecommons.org/licenses/by/4.0/), which permits unrestricted use, distribution, and reproduction in any medium, provided you give appropriate credit to the original author(s) and the source, provide a link to the Creative Commons license, and indicate if changes were made. The Creative Commons Public Domain Dedication waiver (http://creativecommons.org/publicdomain/zero/1.0/) applies to the data made available in this article, unless otherwise stated. 